\title{
The Role of Croatia in Bosnia and Herzegovina: Antemurale Christianitatis as a Policy of Choice
}

\author{
EMIR SULJAGIĆ*
}

ABSTRACT The commentary deals with the history of Croatian interference in BiH in the context of the place that BiH and its Muslims hold in the development of the Croatian national narrative. The pattern based on the myth of Croatia as the "bulwark of Christianity" and "nesting Orientalism" can be identified as underpinning Croatian national and foreign policy in BiH. Croatia is still pursuing its ambitions in BiH under the guise of membership in the EU and NATO and is likely to continue to do so, especially in the absence of a comprehensive political strategy of both organizations for BiH and the region of former Yugoslavia in general.

$\mathrm{n}$ this commentary, I argue that since the dissolution of Yugoslavia in the early 1990s, the central plank of the Republic of Croatia's foreign policy towards Bosnia and Herzegovina (hereafter "BiH" or "Bosnia") has been a consistent and systematic "orientalisation" of $\mathrm{BiH}$ and its Muslim population on the part of the political class of Croatia. The article looks at the Croatian policy towards Bosnia, focusing on the origins of the Croatian project in $\mathrm{BiH}$ that started in the early 1990s -and still lasts, albeit by different means- as well as its historical and cultural roots.

From the moment the Republic of Croatia gained independence in 1992, its political elites sought to re-arrange $\mathrm{BiH}$ in line with their view of Bosnia as a mere sum of three ethnic groups (Bosniaks, Croats, and Serbs). Subsequently, they used different instruments to that end. Whereas in the 1990s Croatia was instrumental in the establishment of a proxy-state in $\mathrm{BiH}$ called "Herceg Bosna," which orchestrated a campaign of mass violence to claim a third of Bosnia's territory and change its ethnic fabric, presently Croatia is pursuing a diplomatic, political, and media campaign tantamount to a hybrid warfare towards $\mathrm{BiH}$ with the ultimate goal to undermine the Bosnian statehood. Croatia's current strategy hinges on the skillful manipulation of
* International University of Sarajevo, Bosnia and Herzegovina 2019, pp. 23-35 
The "othering" of Bosnia's Muslim population has a long history in Croatia; so long, in fact, that one could argue that important elements of Croatian identity have been formed in a binary opposition to Islam and Muslims of BiH

BiH's sizable ethnic Croat population in $\mathrm{BiH} .{ }^{1}$

While the notion of orientalisation is rooted in Edward Said's concept of "orientalism" as "a tradition of thought, imagery and vocabulary" used to create a reality in $\mathrm{BiH}$ that does not exist, or otherwise would not exist, the "othering" of Bosnia's Muslim population has a long history in Croatia; so long, in fact, that one could argue that important elements of Croatian identity have been formed in a binary opposition to Islam and Muslims of BiH. The idea of Croatia as a "bulwark" of European and Christian civilization towers above all other ideas in contemporary mainstream Croatian nationalism. Moreover, Croatian nationalism has also remained substantially trans-sovereign, i.e. based on the assumption that Croatia's national center "is the center of life on both sides of the border" and "historicist." ${ }^{4}$ Croat nationalism remained "trans-sovereign" through the 1990s to this day: "Although Mostar increasingly became the center of Croats in BiH during the 1990s, especially during the existence of Herceg Bosna, Zagreb was and still remains the trans-sovereign center." ${ }^{5}$ "Historicity" is ingrained in the very foundations of the Croat national ideology, tracing its roots in Pavao Ritter Vitezovićs ideas in the $17^{\text {th }}$ century. Vitezović was the first Croatian national ideologue to extend the Croat name to all South Slavs but also based his vision of Croatia on the so-called "historical and state right."

From the dissolution of Yugoslavia, Croatian policy towards $\mathrm{BiH}$ has been based on both the idea of civilizational distinction from (and, by extension, supremacy) and the belief that the Croatian state is responsible for the well-being and political situation of its co-ethnics in $\mathrm{BiH}$ and therefore within its rights to intervene in its sovereign affairs.

From the moment $\mathrm{BiH}$ gained international recognition as a sovereign and independent state in April 1992, Croatia -using the state instruments under the leadership of President Franjo Tuđman- has sought to redefine it from a civic republic into a confederation of ethnic groups, at best. In other words, parallel to the Serbian project during the wars of dissolution of Yugoslavia, there was also an independent and corresponding one for Croats. Whereas the Serbian project was more ambitious in scope and more brazen in the execution, it shared with its Croat counterpart the common goal of dividing and removing from the political map the $\mathrm{BiH}$ state. ${ }^{7}$ In ideological terms, the Croatian project was at the in- 
tersection of several different strands of thinking within the mainstream Croat national ideology that have in common territorial claims on Bosnia and Herzegovina and consider Bosnian Muslims either as lost brothers to be redeemed or the eternal enemy representing the Asiatic other.

The decision to recognize $\mathrm{BiH}$ was spelled out clearly in a letter sent to Alija Izetbegović, President of the Republic of Bosnia and Herzegovina and signed by his Croatian counterpart Tuđman on April 7, 1992. The letter stated that the Republic of Croatia recognizes -rather than under its constitutional name of the Republic of Bosnia and Herzegovina, a former Yugoslav socialist republic- $\mathrm{BiH}$ as "the community of three constituent peoples," simultaneously seeking guarantees for "the sovereign rights of the Croat people" and includes an offer of Croatian citizenship to members of the Croat community in $\mathrm{BiH}{ }^{8}$

Throughout his political career, Tuđman maintained that a sovereign Bosnia and Herzegovina was not an acceptable "solution for the Croat people" because it "was created by the colonial conquest of an Asiatic power (...) from the $15^{\text {th }}$ to $18^{\text {th }}$ centuries, at the expense of Croat people, at the expense of Croat territory." Elsewhere, Tuđman further elaborated his position on BiH and its Muslims: "Personally, as a man who has thought of history, [I] never had illusions as far as Muslims are concerned and their relationship to Croatdom, because I knew that Croats fought Muslims for three centuries, not Turks, but Muslims from Bosnia and that they pushed Croatia to the verge of doom (...) No politician, Radić, Maček or Pavelić, and now me, have managed to establish a working relationship with Muslims." ${ }^{10} \mathrm{He}$ said this in a meeting with a delegation of Bosnian Croats trapped in the besieged Bosnian capital of Sarajevo in December 1993.

In fact, Tuđman was echoing two different strands in the Croat national tradition: one that considered the Bosnian Muslim population the enemy of Christendom and therefore Croats as its shield bearers, and the other of Muslims as a part of the Croat nation that needed to be redeemed and emancipated. In Hajdarpašićs words, Bosnian Muslims played within both Serb and Croat national imagery the "liminal figure (...) that could appear both as a fanatical, relentless oppressor and a strayed but redeemable co-national." 11

In unpacking Tuđman's statements -some of them meticulously recorded in closed meetings with the leadership of the Republic of Croatia and separatist leadership of Bosnian Croats, as well as in his pre-war publications ${ }^{12}-$ it is important to understand two related concepts. One is antemurale Christianitatis -the notion that Croatia is the shield and bulwark of Christianity and Europe- and the other that of "nesting Orientalisms," elaborated by Milica Bakić-Hayden.

Bakić-Hayden places "nesting Orientalisms"13 within the context of appropriation and manipulation of the designation of the "other" in former 


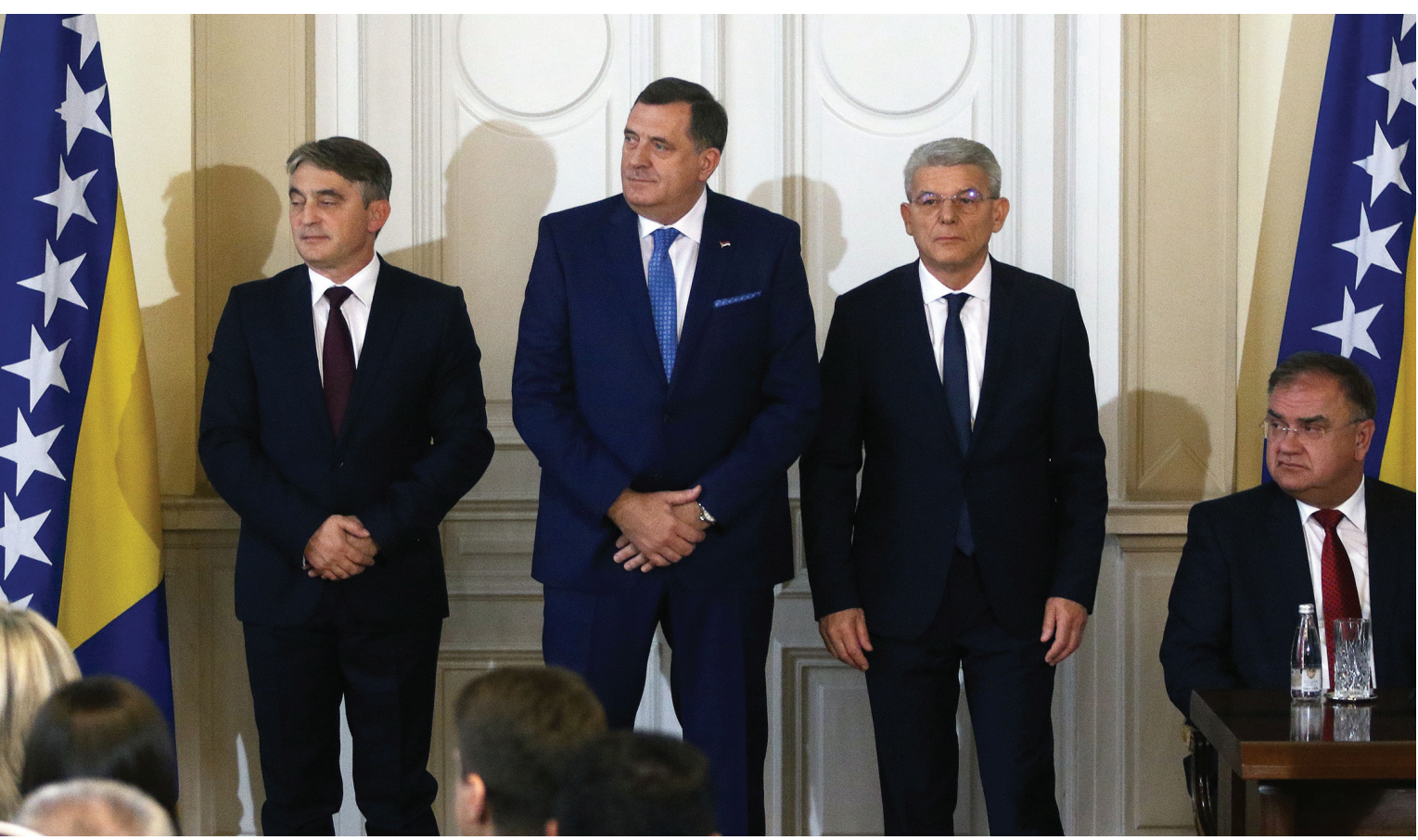

Newly elected

members of

Bosnia and

Herzegovina's

tripartite

presidency,

Bosnian Croat

member Komsic

(L), Bosnian Serb

member Dodik

(C), and Bosnian

Muslim member

Dzaferovic (R)

attend their

inauguration ceremony on

November 20,

2018.

STR / AFP /

Getty Images
Yugoslavia: "Thus, while Europe as a whole has disparaged not only the orient 'proper' but also the parts of Europe that were under oriental Ottoman rule, Yugoslavs who reside in areas that were formerly the Habsburg monarchy distinguish themselves from those in areas formerly ruled by the Ottoman Empire, hence 'improper."'14 Furthermore, she notes, "the legacy of Islamic culture and the Muslim population left behind after the collapse of the Ottoman Empire presented Europe with the problem of Muslim integration, particularly in those areas that had been under Ottoman rule (...)."15

Similarly, during the Muslim-Croat confrontation in Bosnia, in 1993, a Bosnian Croat official warned that it is necessary "to distinguish the es- sentially different mental make-up and value system of the writer of the Islamic Declaration [an allusion to Bosnian President Alija Izetbegović] and his followers from those of the European-oriented Christians, even if the latter are on the margins of civilization" [an allusion to Orthodox Serbs]. ${ }^{16}$ But, more importantly: "The implication is that the 'real' identity of persons or groups is to be found in the pre-Yugoslav past. Another striking feature of this process has been a characterization of the national 'other' in, for the most part, reductionist terms and simple conceptions juxtaposed to complexity of self-characterization. What constitutes 'real' identity in this context and is most often invoked, both in domestic debates and foreign reports, are the religious/cultural 'essences."' 17 
Further clarification is required in order to understand the Croatian political equation in Bosnia and Herzegovina, that of the importance of the antemurale myth for the Croat national identity and narrative. The antemurale myth, as Pal Kolsto argues, rather than on the uniqueness of the group posits that "the group is now included in some larger and allegedly superior cultural entity that enhances its status vis-à-vis other groups who do not belong." ${ }^{18}$ More to the point, the antemurale myth "stresses not only that the group is an integral part of the true civilization, but also that it represents its very outpost" sacrificing itself "in order to save the larger civilization of which it is a part." ${ }^{19}$

The notion of antemurale Christianitatis has deeper roots, but it became particularly salient in Croatia towards the end of the $15^{\text {th }}$ century in the context of Croatian defeats under the weight of the expanding Ottoman Empire. $^{20}$ Croatian aristocracy appealed for aid to the diet of the German states assembled at Nuremberg in 1522 reminding that "Croatia is the shield and the door of Christianity." The same characterization can be found the following year in a letter to Pope Adrian VI. ${ }^{21}$ The strength of the myth remained so pervasive that, according to Ivo Žanić, "the concept of 'bulwark' was the basis for the development of modern patriotic ideology and the vision of national space." 22

The following section of the commentary deals with major thinkers and ideologues of Croat nationalism starting in the $16^{\text {th }}$ century all the way

\section{The notion of antemurale}

Christianitatis has deeper

roots, but it became

particularly salient in Croatia

towards the end of the $15^{\text {th }}$

century in the context of

Croatian defeats under the

weight of the expanding

Ottoman Empire

up to the end of the $20^{\text {th }}$ century; it is not an exhaustive overview of Croat nationalism, but rather a historical overview of some of its key features in relation to Bosnia and Herzegovina and its Muslim population. I argue that the idea, notion, and actual shape and size of Croatia evolved over the centuries, but an obsession with Bosnia and Herzegovina continued to permeate Croat national thinking.

From the very beginning, the vision of Croatian national space included parts of Bosnia and Herzegovina. Already in 1699, Pavao Ritter Vitezović, a Croatian nobleman protesting the demarcation between the Austro-Hungarian and the Ottoman Empire following the Vienna siege, produced a document delineating "the frontiers of the whole Croatia." ${ }^{23}$ His vision of Greater Croatia -called Croatia Rediviva- was based on the socalled historic right and included the whole of Bosnia and Herzegovina. ${ }^{24}$ It is impossible to underestimate the importance of Vitezovićs program- 


\section{The notion of this self-}

proclaimed historic claim

over Bosnia and Herzegovina

permeated the mainstream

of Croatian national program

until after World War I and into

the inter-war period of the

Kingdom of Serbs, Croats, and

Slovenes, which was renamed

the Kingdom of Yugoslavia in

1931 returning from the raid reaching as far as present-day Slovenia as "a catastrophe that shaped the historical development of not only southern, but the whole of Croatia." 27 The battle quickly became the subject of both folk and "high" poetry and gradually part of the Croatian culture and national identity. ${ }^{28}$ The memory of the battle found its way into an entire literary genre aptly called antiturcica that developed in Croatia -as well as elsewhere in Europe- in the $16^{\text {th }}$ century. $^{29}$

The idea of Croatia's historical claim over Bosnia and Herzegovina was picked up in the $19^{\text {th }}$ century by Ante Starčević, frequently referred to in Croatian historiography as the "father of the country." Starčević had different ideas about Muslims of Bosnia and Herzegovina and considered them to be not just Croats, but "the purest, the least corrupt part of our people [Croats]." ${ }^{30}$ The notion of this self-proclaimed historic claim over Bosnia and Herzegovina permeated the mainstream of Croatian national program until after World War I and into the inter-war period of the Kingdom of Serbs, Croats, and Slovenes, which was renamed the Kingdom of Yugoslavia in 1931.

It is worth noting that the Croat national policy towards Bosnian Muslims at the end of the $19^{\text {th }}$ and the beginning of $20^{\text {th }}$ century was taking place within the larger context of "struggles around Muslim's status as potential co-nationals" between the Serb and Croat national camp. ${ }^{31}$ The division within the Croat camp 
between 1878 and 1914 went beyond the issue of conversions to Catholicism which agitated the non-Catholic public in $\mathrm{BiH}$ under Austro-Hungarian occupation -so much so that some authors take a particular conversion crisis in May 1899 as the beginning of political organizing among Muslims ${ }^{32}$ - and centered on the key question in the battle between Croat lay intelligentsia and the Catholic church hierarchy, that of whether Muslims could be considered to be Croats, as well as Catholics. ${ }^{33}$

Stjepan Radić, an ideologue and key figure in the Croat Peasant Party (Hrvatska Seljačka Stranka, HSS) in the inter-war period, who opposed the establishment of the Kingdom of Serbs, Croats, and Slovenes under the Serbian Karađorđević dynasty, continued to employ the tactics of trying to co-opt Bosnian Muslims and claim a historical right to Bosnia and Herzegovina. ${ }^{34}$ Following Radić's assassination in the Yugoslav parliament by Puniša Račić, a Serbian Radical deputy, in June $1928,{ }^{35}$ the HSS party -which by then had become the centerpiece of the Croatian national movement- was taken over by Vladko Maček.

The tensions between the Serbs and the Croats reached a climax in the late 1930s. In August 1939, in order to resolve them, Serb Prime Minister Dragiša Cvetković and Maček reached a deal whereby Bosnia and Herzegovina ceased to exist as a distinct political and administrative entity. Under the Cvetković-Maček Agreement, they split $\mathrm{BiH}$ between
Serbia and Croatia, with the autonomous region of Croatia (also known as Banovina Hrvatska) annexing roughly one-third, while the Serbian region kept the remainder.

When, after World War II, Maček was asked about the status accorded to the Muslim population of Bosnia and Herzegovina in the deal, he -who is lionized in present-day Croatia as a great statesman- responded: "We agreed [that] when it comes to Bosnia and Muslims, to regard Muslims as if they don't exist. And that is how we acted." ${ }^{36}$ The initiative for the division of Bosnia came at the initiative of a Croatian political establishment that continued to view the arrangement as a way of accommodating the dispute with the Serb-dominated regime in Belgrade. ${ }^{37}$

After the Axis powers attacked Yugoslavia in April 1941, Bosnia and Herzegovina was occupied by the Nazi satellite Independent State of Croatia (Nezavisna Država Hrvatska, NDH) under the leadership of the Ustasha Poglavnik Ante Pavelić, a notorious right wing politician and self-styled fascist. ${ }^{38}$ However, the antemurale myth remained salient even after its establishment and throughout the existence of $\mathrm{NDH}$, whose genocidal regime systematically targeted Jews, Roma, Serbs, and Communists between 1941 and 1945. Whilst the new regime adopted Starčevićs views on Muslims officially designating them as "Croats of Islamic faith," ${ }^{39}$ the antemurale myth continued to underpin the official ideology of Croatian nationalism as not only "local patrio- 


\section{The Catholic Church, including}

its senior clergy, has not

stayed away from contributing

to the stigmatization of the

Muslim population of Bosnia

and Herzegovina, building

upon the antemurale myth tism, but loyal service to the whole of [the] white West." 40

Kisić-Kolanović argues that the basis for the Greater Croatian obsession with Bosnia and Herzegovina rests in its geography and the view that without the incorporation of Bosnia and Herzegovina in the Croatian state, it would be considered as "spatially incomplete." 41 Tuđman echoes this argument almost verbatim in the meeting with the Bosnian Croat leadership in December 1991. He literally stated: "Therefore, we should not count Bosnia and Herzegovina as God-given (...) the establishment of Bosnia and Herzegovina has placed Croatia in an impossible situation in the territorial sense. We cannot organize an independent Croatia in the administrative sense like this, let alone defense-wise." ${ }^{42}$

On this occasion, Tuđman was merely repeating his public and longheld views on Bosnia and Herzegovina. In 1990, Tuđman wrote in his book National Question in Contemporary Europe that: "Granting Bosnia and Herzegovina the status of a sep- arate federal state made the territory and geographic position of Croatia in the sense of economy and traffic ultimately unnatural and very adverse in the widest national and political sense." As far as Bosnian Muslims are concerned, Tuđman wrote that "the Muslim population in a large majority, in terms of ethnic composition and language, is indisputably of Croat origin." ${ }^{33}$ Whereas it is tempting to dismiss Tuđman's writings today, it should be kept in mind in the words of Ivo Banac that he "legitimated himself in his various writings in which it is important to recognize his entirely original contributions to the Croat national policy" 44 and that he was in a unique position to act on his beliefs with the full might of the Croatian state.

As a result, at the beginning of the dissolution of Yugoslavia, three distinct but interrelated positions emerged within the Croatian national mainstream politics in regards to Bosnia and Herzegovina by the beginning of the dissolution of Yugoslavia: (i) Croatia historically acted as a bulwark of Christianity in opposition to the Orient represented by Bosnian Muslim population; (ii) Croatian state, and in fact, Croatian statehood itself, was untenable without incorporating whole or parts of Bosnia and Herzegovina; and (iii) the Muslims continued to be represented as either Oriental aliens or long-lost brethren who needed to be emancipated and embraced within the Croat nation.

During the early 1990s and after the signing of the Dayton Peace Accords 


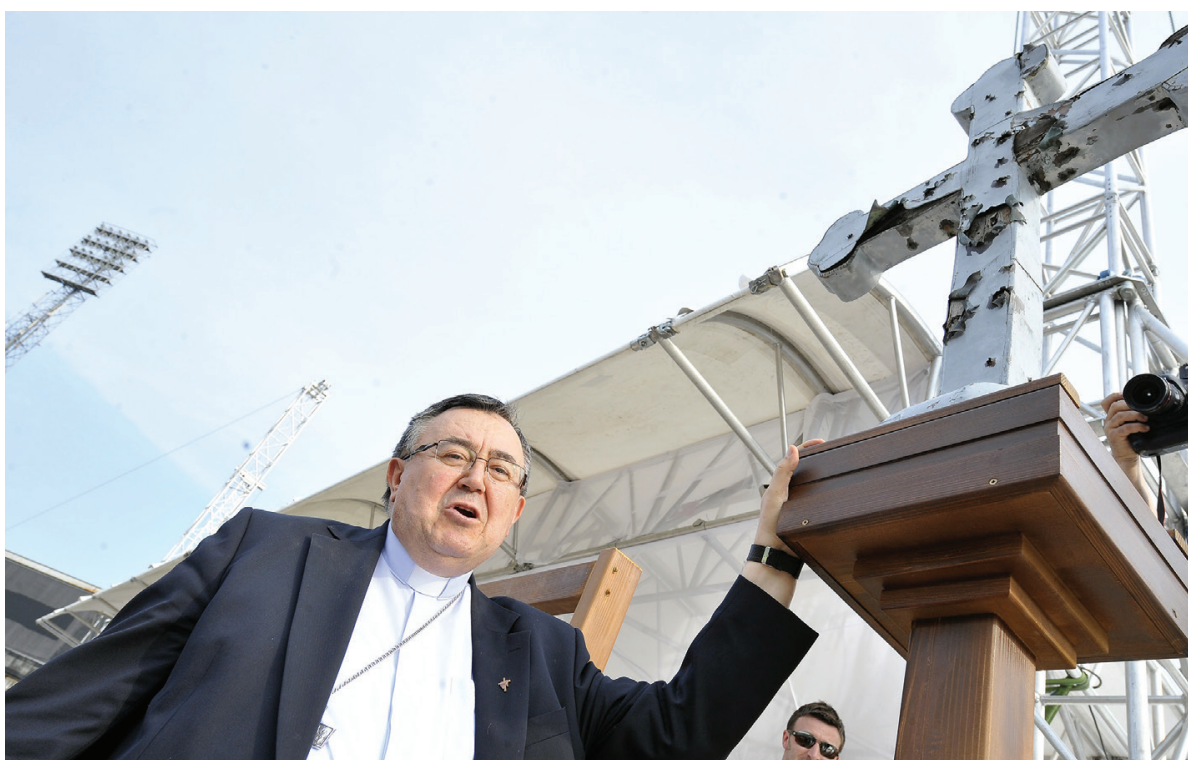

in 1995 , both the key instrument in the execution of the policy based on the political and cultural pattern of incorporation of Bosnian territory and cooptation -or, alternatively, ethnic cleansing- of Bosnian Muslim population was the main political platform of the leading Croat ethnic party in Bosnia and Herzegovina, the Croat Democratic Community of Bosnia and Herzegovina (HDZ $\mathrm{BiH})$, a sister and proxy party of its namesake in Croatia. With the sole exception of the president of HDZ $\mathrm{BiH}$ Mate Boban (who died in 1997), the entire political and military leadership of HDZ was tried before the International Criminal Tribunal for the Former Yugoslavia (ICTY) and found guilty of crimes against humanity. Nonetheless, Croatia still continues to use $\mathrm{HDZ} \mathrm{BiH}$ in its pursuit of the strategy of undermining the sovereignty and territorial integrity of Bosnia and Herzegovina.
Meanwhile, the Catholic Church, including its senior clergy, has not stayed away from contributing to the stigmatization of the Muslim population of Bosnia and Herzegovina, building upon the antemurale myth. For instance, the archbishop of Sarajevo, Cardinal Vinko Puljić, the top figure of the Catholic Church in Bosnia and Herzegovina, commented recently in an interview with the Italian Religious Information Service: "Unfortunately, Europe does not know Islam well and does not understand what it means to live side by side with Islamic radicalism." ${ }^{45}$

The approach the Republic of Croatia has adopted in undermining Bosnian sovereignty is multifaceted. First, Croatia continues to covet Bosnia and Herzegovina. The preamble of the Croatian Constitution views the Cvetković-Maček agreement and the establishment of Banovina $\mathrm{Hr}$ -
The Head of the Catholic Church in Bosnia, Cardinal Vinko Puljić, has contributed to the stigmatization of the Muslim population of Bosnia and Herzegovina, building upon the antemurale myth. ELVIS BARUKCIC / AFP / Getty Images 
Croatia is now pursuing its ambitions in Bosnia and Herzegovina under the guise of membership of the European Union and NATO and is likely to continue to do so the millet system. ${ }^{48}$ In the meantime, Croatia's political elite, led by President Kolinda Grabar-Kitarović and Prime Minister Andrej Plenković, has intensified its campaign of meddling in the political process in $\mathrm{BiH}$, using its membership in the EU and NATO to further undermine the standing and sovereignty of Bosnia and Herzegovina. ${ }^{49}$

The third and final prong is the use of $\mathrm{HDZ} \mathrm{BiH}$ to pursue war-time goals of transforming the constitutional and political system of Bosnia and Herzegovina along the lines defined by Franjo Tuđman in the early 1990s. To this end -following the December 2016 decision of the Constitutional Court of $\mathrm{BiH}$ that ruled partially in favor of a complaint lodged by former HDZ politician Božo Ljubić, essentially arguing that Croats from Sarajevo, Tuzla, and Bihać should be legally banned from becoming members of the House of Peoples of the Federation of Bosnia and Herzegovina- $\mathrm{HDZ} \mathrm{BiH}$ has hijacked the political process in the country. ${ }^{50}$ Presently, $\mathrm{HDZ} \mathrm{BiH}$ is threatening a total political shutdown following the general elections held in October 2018 in which its candidate for the tripartite Presidency of $\mathrm{BiH}$ lost to the civic-minded ethnic Croat Željko Komšić. Most recently, the Central Election Commission of $\mathrm{BiH}$ devised a formula for the election of delegates to the House of Peoples of Bosnia and Herzegovina that Bosnian political scientist Jasmin Mujanović described as "virtual coup." 51 The country's political system now has reached the stage of complete gridlock as a result 
of the policy pursued by Croatia and its proxy $\mathrm{HDZ} \mathrm{BiH}$.

In conclusion, as this commentary has attempted to demonstrate, there is a long history of Croatian pretensions on Bosnia and Herzegovina, underpinned by a political and cultural pattern that sees the country and its Muslim population as less equal and less European. That pattern is likely to continue playing a central place in Croatia's policies towards Bosnia and Herzegovina. In fact, Croatia is now pursuing its ambitions in Bosnia and Herzegovina under the guise of membership of the European Union and NATO and is likely to continue to do so, especially in the absence of a comprehensive political strategy for $\mathrm{BiH}$ and the region of the former Yugoslavia in general on the part of both the EU and NATO. In other words, Franjo Tuđman may be dead, but his legacy of racial ideas about Bosnia and Herzegovina and the Bosnian Muslims is still very much alive.

\section{Endnotes}

1. According to the census from 2013, the number of Croats living in $\mathrm{BiH}$ was 544,780 or 15.4 percent of the population. Statistics Agency for Statistics of Bosnia and Herzegovina, retrieved February 18, 2019, from http://www.popis.gov. ba/popis2013/knjige.php?id=2.

2. Edward Said, Orientalism, (London: Penguin Books, 1995), p. 5.

3. Vedran Obućina, "Hrvatski Transsuvereni Nacionalizam u BIH," Političke Analize, Vol. 1, No. 4 (2010), pp. 21-24.

4. Ivo Banac, The National Question in Yugoslavia, (Ithaca: Cornell University Press, 1992), p. 73.

5. Obućina, "Hrvatski Transsuvereni Nacionalizam u BIH," p. 21.
6. Banac, The National Question in Yugoslavia, p. 74.

7. The International Criminal Tribunal for the former Yugoslavia ruled in a landmark judgment of the political and military leadership of Croatia's proxy in Bosnia and Herzegovina -"Croatian Community of Herceg Bosna"- existed as no more than a form of occupation of part of Bosnian territory and that their actions amounted to a "joint criminal enterprise" established, funded, and designed by the Republic of Croatia which was to be either annexed or become an (semi)independent entity within Bosnia and Herzegovina responsible directly to Zagreb. See, Appeals Chamber Judgement in the Prosecutor v. Jadranko Prlić, Bruno Stojić, Slobodan Praljak, Milivoj Petković, Valentin Ćorić, Berislav Pušić, (November 29, 2017); Trial Chamber Judgement in the Prosecutor v. Jadranko Prlić, Bruno Stojić, Slobodan Praljak, Milivoj Petković, Valentin Ćorić, Berislav Pušić, (May 29, 2013), retrieved December 22, 2018, from http://www.icty.org/case/prlic/4\#pressrel.

8. "Decision Recognizing the Socialist Republic of Bosnia and Herzegovina as a Sovereign and Independent State, Republic of Croatia," (April 7, 1992).

9. Excerpt of minutes of a meeting between President Tuđman and a delegation of the $\mathrm{HDZ} \mathrm{BiH}$ in the presence of other dignitaries of the Republic of Croatia held in Zagreb, (December 27, 1991).

10. Minutes of the talks of the President of the Republic of Croatia Franjo Tuđman with representatives of the Croatian Coordination Committee of Herceg Bosna, in the Presidential Palace, Zagreb, (December 15, 1993).

11. Edin Hajdarpašić, Whose Bosnia?: Nationalism and Political Imagination in the Balkans, (Ithaca: Cornell University Press, 2015), p. 80.

12. Franjo Tuđman, Nacionalno Pitanje u Suvremenoj Europi, (Zagreb: Matica Hrvatska, 1990), pp. 120-121.

13. "The gradation of 'Orients' that I call 'nesting orientalisms' is a pattern of reproduction of the original dichotomy upon which Orientalism is premised. In this pattern, Asia is more 'East' or 'other' than eastern Europe; within eastern Europe itself this gradation is reproduced with the Balkans perceived as most 'eastern'; within the Balkans there are similarly constructed hierarchies." Milica Bakić-Hayden, "Nesting Orientalisms: The Case of Former Yugoslavia," Slavic Review, Vol. 54, No. 4 (Winter 1995), p. 918.

14. Bakić-Hayden, “Nesting Orientalisms,” p. 922. 
15. Bakić-Hayden, "Nesting Orientalisms," p. 922.

16. Bakić-Hayden, “Nesting Orientalisms," p. 929.

17. Bakić-Hayden, “Nesting Orientalisms," p. 923.

18. Pal Kolsto, "Introduction: Assessing the Role of Historical Myths in Modern Society," in Pal Kolsto (ed.), Myths and Boundaries in South-Eastern Europe, (London: Hurst and Company, 2005), p. 20.

19. Kolsto, "Introduction," p. 20.

20. The term was first used by the French theologian Bernard of Clairvaux in referring to the Frankish garrison defending the town of Edessa (present-day Şanlıurfa in Turkey) in 1143 the most remote Christian principality in the Middle East, which fell to the Seljuk Turks the following year. Ivo Žanić, "Simbolični Identitet Hrvatske u Trokutu Raskrižje-predziđe-most," in Husnija Kamberović (ed.), Historijski Mitovi na Balkanu, (Sarajevo: Institut za Istoriju u Sarajevu, 2003), p. 163.

21. Žanić, "Simbolični Identitet Hrvatske u Trokutu Raskrižje-predziđe-most," p. 166.

22. Žanić, "Simbolični Identitet Hrvatske u Trokutu Raskrižje-predziđe-most," p. 166.

23. Banac, The National Question in Yugoslavia, p. 73.

24. Banac, The National Question in Yugoslavia, p. 73; Borna Fuerst-Bjeliš and Ivan Zupanc, "Images of the Croatian Borderlands: Selected Examples of Early Modern Cartography," Hrvatski Geografski Glasnik, Vol. 69, No. 1 (2007), p. 11, retrieved from https://doi.org/10.21861/HGG.2007.69.01.01.

25. Ivo Banac, "The Redivived Croatia of Pavao Ritter Vitezović," Harvard Ukrainian Studies, Vol. 10, No. 3-4 (December 1986), p. 499.

26. Banac, "The Redivived Croatia of Pavao Ritter Vitezović," p. 505.

27. For a detailed reconstruction of the battle, see, Hrvoje Kekez, "Bernardin Frankapan i Krbavska Bitka: Je li Spasio Sebe i Malobrojne Ili Je Pobjegao iz Boja?" Modruški zbornik, Vol. 3, No. 3 (2009), pp. 65-101.

28. Suzana Miljana and Hrvoje Kekez, "The Memory of the Battle of Krbava (1493) and the Collective Identity of the Croats," Hungarian Historical Review, Vol. 4, No. 2 (2015), pp. 283-313.

29. Violeta Moretti, "Oratio pro Croatia Bernardina Frankapana," Modruški Zbornik, Vol. 3, No. 3 (2009), pp. 165-186.

30. Mirjana Gross, Povijest Pravaške Ideologije, (Zagreb: Institut za Hrvatsku Povijest, 1973), p. 33.
31. Hajdarpašić, Whose Bosnia?, p. 16; Mirjana Gross, "Hrvatska Politika u Bosni i Hercegovini od 1878. do 1914," Historijski Zbornik, XIX-XX, (19661967), pp. 14-15.

32. Admir Mulaosmanović, Kratka Politička Istorija Bošnjaka, (Sarajevo: Stav/IUS, 2018), p. 9.

33. Robin Oakey, Taming Balkan Nationalism: The Habsburg 'Civilizing Mission' in Bosnia, 18781914, (Oxford: Oxford University Press, 2007), pp. 118-121; Mustafa Imamović, Pravni Položaj $i$ Unutrašnjo-politički Razvitak Bosne i Hercegovine od 1878. do 1914., (Sarajevo: Magistrat, 2007), p. 125.

34. Ivan Mužić, Stjepan Radić, and Kraljevini Srba, Hrvata i Slovenaca, (Zagreb: Matica Hrvatska, 1990), pp. 21-26; Atif Purivatra, Jugoslovenska Muslimanska Organizacija u Političkom Životu Kraljevine Srba, Hrvata i Slovenaca, (Sarajevo: Svjetlost, 1974), pp. 198-199, 215.

35. Hrvoje Matković, Povijest Hrvatske Seljačke Stranke, (Zagreb: Naklada Pavičić, 1999), pp. 521.

36. Branko Miljuš, Sporazum 1939, (Windsor: Avala Printing and Publishing Company, 1957), p. 15.

37. Šaćir Filandra, Bošnjačka Politika u XX. Stoljeću, (Sarajevo: Sejtarija, 1998), p. 126.

38. Enver Redžić, Bosna i Hercegovina u Drugom Svjetskom Ratu, (Sarajevo: OKO, 1998), pp. 117121.

39. Nada Kisić Kolanović, Muslimani i Hrvatski Nacionalizam, (Zagreb: Školska Knjiga, 2009), p. 37.

40. Kolanović, Muslimani i Hrvatski Nacionalizam, p. 270.

41. Kolanović, Muslimani i Hrvatski Nacionalizam, p. 40.

42. Excerpt of minutes of a meeting between President Tuđman, and a delegation of the HDZ $\mathrm{BiH}$ in the presence of other dignitaries of the Republic of Croatia held in Zagreb, (December 27, 1991).

43. Tuđman, Nacionalno Pitanje u Suvremenoj Europi, pp. 120-121.

44. Ivo Banac, "Independent Croatia: History, Issues and Policy," International Relations Quarterly, Vol. 2, No. 1 (Spring 2011), p. 6.

45. "Bosnia-Erzegovina: Card. Puljic (Sarajevo) ad Acs, 'Contro il Radicalismo l'Europa Custodisca le Sue Radici Cristiane,"' Servizio Informazione Religiosa, (August 1, 2018) retrieved January 15, 2019, from https://www.agensir.it/quotidiano/ 
2018/8/1/bosnia-erzegovina-card-puljic-sarajevo-ad-acs-contro-il-radicalismo-leuropa-custodisca-le-sue-radici-cristiane/.

46. “Ustav Republike Hrvatske (pročišćeni tekst), Narodne Novine," retrieved December 26, 2018, from https://www.zakon.hr/z/94/Ustav-Republike-Hrvatske.

47. "Deklaracija o Domovinskom Ratu, Narodne Novine 102/2000," (October 17, 2000), retrieved December 26, 2018, from https://narodne-novine. nn.hr/clanci/sluzbeni/2000_10_102_1987.html.

48. "Deklaracija Hrvatskog Sabora o Položaju Hrvatskog Naroda u Bosni i Hercegovini," (December 7, 2018).

49. See, "Plenković Najavio Analizu Izbora u BiH na Vijeću EU," N1, (November 14, 2018), retrieved from http://hr.n1info.com/Vijesti/a347577/Plenkovic-najavio-analizu-izbora-u-BiH-na-VijecuEU-a.html; "Plenković na Sorboni: Jednakost Hrvata u BiH kompromitirana," N1, (October 16, 2018), retrieved from http://ba.n1 info.com/Svijet/ a291540/Plenkovic-na-Sorbonni-Jednakost-Hrvata-u-BiH-kompromitirana.html; "Is Croatia Un- dermining Bosnia's Sovereignty," Al Jazeera, (December 20, 2018), retrieved from https://www. aljazeera.com/indepth/features/croatia-undermining-bosnias-sovereignty-181218142705856. html; Jasmin Mujanović, "Croatian Ruling Party's Dangerous Meddling in Bosnia," Balkan Insight, (October 24, 2018), retrieved from http://www. balkaninsight.com/en/article/croatian-rulingparty-s-dangerous-meddling-in-bosnia-10-232018.

50. Emir Suljagić, "Bosnia: Heading Towards Institutional Gridlock," Italian Institute for International Political Studies, (May 16, 2018), retrieved from https://www.ispionline.it/en/pubblicazione/ bosnia-heading-towards-institutional-gridlock20532; Daniel Serwer, "Bosnia's Teapot Tempest," Peacefare.net, (May 2, 2018), retrieved from https:// www.peacefare.net/2018/05/02/bosnias-teapottempest/.

51. Jasmin Mujanović, "A Virtual Coup in Bosnia," Balkan Insight, (December 24, 2018), retrieved from http://www.balkaninsight.com/en/article/ croatian-ruling-party-s-dangerous-meddling-inbosnia-10-23-2018. 


\section{thenewturkey.org}

Published by SETA Foundation

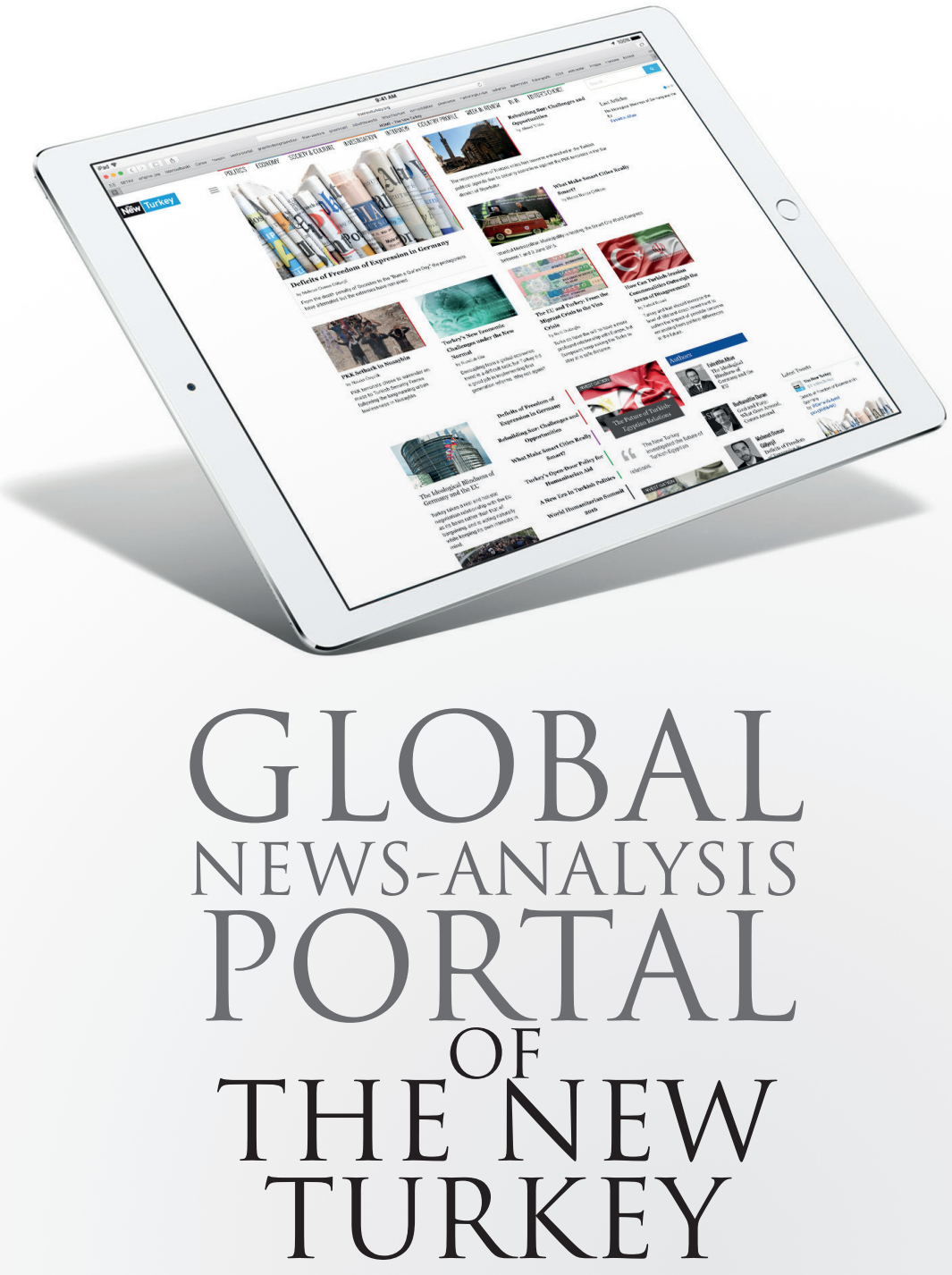

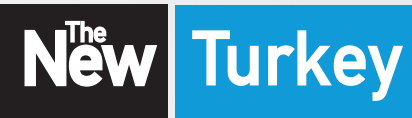

